\title{
RESEARCH
}

Open Access

\section{Ethnobotanical survey of medicinal plant species used by communities around Mabira and Mpanga Central Forest Reserves, Uganda}

Savina Asiimwe ${ }^{1}$, Jane Namukobe ${ }^{2^{*}}$, Robert Byamukama ${ }^{2}$ and Betty Imalingat ${ }^{2}$

\begin{abstract}
Background: Medicinal plants form an integral part of many health care systems in Uganda. This study aimed at documenting the therapeutic importance of plant species used in primary health care among communities living adjacent to Mabira and Mpanga forest reserves in Central Uganda.
\end{abstract}

Methods: An ethnobotanical study was conducted between April and June 2018 in 7 villages adjacent to Mpanga and 6 villages adjacent to Mabira central forest reserves. Information was obtained from 28 respondents identified using snowball and purposive sampling techniques and interviewed using semi-structured questionnaires. Descriptive statistics were used to present the data. The quantitative analysis of data was done using fidelity level, informant consensus factor, and percent respondent knowledge indices.

Results: A total of 136 medicinal plants were recorded. The plant species classified into 55 families were grouped under 14 medical categories with the highest number of plant species being used for digestive disorders (44\%), followed by respiratory (38\%) and dermatological disorders (36\%). Hoslundia opposita Vahl was mentioned by $71 \%$ of the respondents for treating 22 disease conditions. Plant Family Fabaceae was the most represented with 16 species. Informant consensus agreement was high (0.7) for respiratory disorders. The fidelity level was $100 \%$ for Bidens pilosa L. and Callistemon citrinus Skeels for treating wounds and cough, respectively. Plant remedies were mainly prepared by decoction (31\%) and administered orally (36\%). A large number of plants (61\%) were harvested from wild habitats. Herbs (50\%) and leaves (50\%) contributed the highest percentage of plant biological forms and parts used in remedy preparation.

Conclusion: This study recorded plant species with the potential to treat a wide range of illnesses. This is reflected in the high diversity of the recorded species used for medicinal purposes. Pharmacological studies on the plants with high percentage use values and fidelity levels are needed to validate their uses in the management of the said therapeutic applications. Further research on the isolation and characterization of the plant active compounds could lead to the discovery of new potential drugs.

Keywords: Ethnobotany, Medicinal plants, Conservation, Percent use-value informant consensus factor, Mabira, Mpanga, Uganda

\footnotetext{
* Correspondence: jnamukobe@gmail.com

${ }^{2}$ Department of Chemistry, Makerere University, P.O Box 7062, Kampala,

Uganda

Full list of author information is available at the end of the article
}

(c) The Author(s). 2021 Open Access This article is licensed under a Creative Commons Attribution 4.0 International License, which permits use, sharing, adaptation, distribution and reproduction in any medium or format, as long as you give appropriate credit to the original author(s) and the source, provide a link to the Creative Commons licence, and indicate if changes were made. The images or other third party material in this article are included in the article's Creative Commons licence, unless indicated otherwise in a credit line to the material. If material is not included in the article's Creative Commons licence and your intended use is not permitted by statutory regulation or exceeds the permitted use, you will need to obtain permission directly from the copyright holder. To view a copy of this licence, visit http://creativecommons.org/licenses/by/4.0/. 


\section{Introduction}

Plants increasingly continue to form the basis of primary health care in many parts of the world $[1,2]$. In many developing countries, a large proportion of the population relies on traditional medicine to meet their primary health care needs [2]. In Africa, traditional medicine has been part of the peoples' culture, and indigenous knowledge of medicinal plants is a source of new ideas for modern pharmaceutical science [3, 4]. Likewise, in Uganda, phytotherapy still maintains an important role in meeting the primary health care needs of more than $80 \%$ of the population [5-7]. Research shows that many people take a wide range of natural products in addition to the conventional therapeutic products to manage various ailments $[5,8-14]$. The increasing population of Uganda at more than 40 million makes people vulnerable to diseases and infections, due to congestion in many areas. This makes herbal medicine a better and cheaper alternative source of primary health care, especially in rural areas where modern medical services are scarce and expensive to the low-income earners. The increasing population also leads to the search for settlement land, leading to encroachment on forest resources, hence making the herbal medicines vulnerable to lose. Currently, the Uganda government has specifically upscaled the use of herbal medicine and is in the process of integrating it into the mainstream health care system [15].

The purpose of this study was to document medicinal plant uses and associated indigenous knowledge for the management of various ailments among different population groups living adjacent to Mabira and Mpanga forest reserves in central Uganda. The recorded data on respondents' age, gender, and knowledge transfer was analyzed. This is part of an initiative to document data for future phytochemical and pharmacological studies which can act as a starting point for future discovery of drugs for various ailments. The research also contributes to the conservation and preservation of medicinal plants and traditional knowledge. Documenting medicinal plant species may also help to preserve indigenous people's cultural heritage for future generations, since it has been passed on orally for generations by elders [16].

\section{Material and methods}

\section{Study area}

This study was conducted in 7 villages adjacent to Mpanga and 6 villages adjacent to Mabira central forest reserves (CFR) (Fig. 1). The villages were within a distance of less than $5 \mathrm{~km}$ from the forest, hence enabling people to harvest forest resources. Mpanga forest reserve is situated in the Mpigi District about $37 \mathrm{~km}$ from Kampala city. Mpanga forest is protected as a scientific research site and an ecotourism center that offers a wide range of tourism activities including bird watching and forest hiking. It is one of the smallest natural equatorial rainforests with unique tree species for making drums. The forest reserve borders with districts of Wakiso to the North and East, Mityana to the North West, Butambala to the West, Kalangala to the South, and Kalungu to the South West. The site is endowed with about 500 species of trees and shrubs [17]. The dominant tree species in the Mpanga forest is the hard and weather-resistant Celtis mildbraedii Engl and Bosqueia phoberos Baill [18]. Mpanga is surrounded by a community of Baganda, whose main activity is drum making [17]. Mpigi District, often referred to as Buganda Region, is situated in the Central Region of the country and lies between latitudes $0.2^{\circ}$ South and $0.4^{\circ}$ North and longitudes $31.8^{\circ}$ East and $32.3^{\circ}$ East, with an average altitude of 1100-1400 m above sea level. The district has a bimodal rainfall pattern (March-May \& September November) with an average rainfall amount of 1320 $\mathrm{mm}$, average annual maximum temperatures range between $22.5^{\circ} \mathrm{C}$ and $27^{\circ} \mathrm{C}$, and average relative humidity between $80 \%$ and $95 \%$ especially in forest areas. Mpigi District has 40 health units of different categories, many of which have insufficient basic equipment like a microscope, stethoscope, and medicine to offer proper health care services [19]. Because of the cross-cutting nature of health issues, there is a need for an integrated approach to health [20]. The communities however do still depend on the forest for firewood, charcoal, and medicinal herbs [17].

Mabira forest reserve is located along the main Kampala - Jinja highway, in Buikwe District. The mean annual temperature is $21^{\circ} \mathrm{C}-25^{\circ} \mathrm{C}$, minimum of $16-17^{\circ} \mathrm{C}$, and maximum of $28-29^{\circ} \mathrm{C}$ [17]. The vegetation of Mabira CFR was classified as a "medium altitude moist semi-deciduous forest with a natural habitat of 312 indigenous tree species of which Caesalpinia volkensii Harms is endemic [21]." Mabira forest is an important area for ecological and environmental conservation of biodiversity and habitat to many animal and plant species. The forest reserve has tea and sugarcane plantations surrounding it, where some local people are engaged as laborers. Local communities grow food crops like maize, beans, bananas, groundnuts, sweet potatoes, and vegetables mainly for subsistence consumption. However, in 2007, the government of Uganda was determined to give away up to 7000 ha of Mabira forest to Mehta to expand his sugar estate [22]. This was after the sugar prices tripled, and the Uganda government took the opportunity to try to convince the public that the only way to bring down prices was to increase sugar production by giving away part of the Mabira forest to the Sugar Corporation of Uganda Limited (SCOUL) to produce more sugar. But this proposal met stiff resistance 


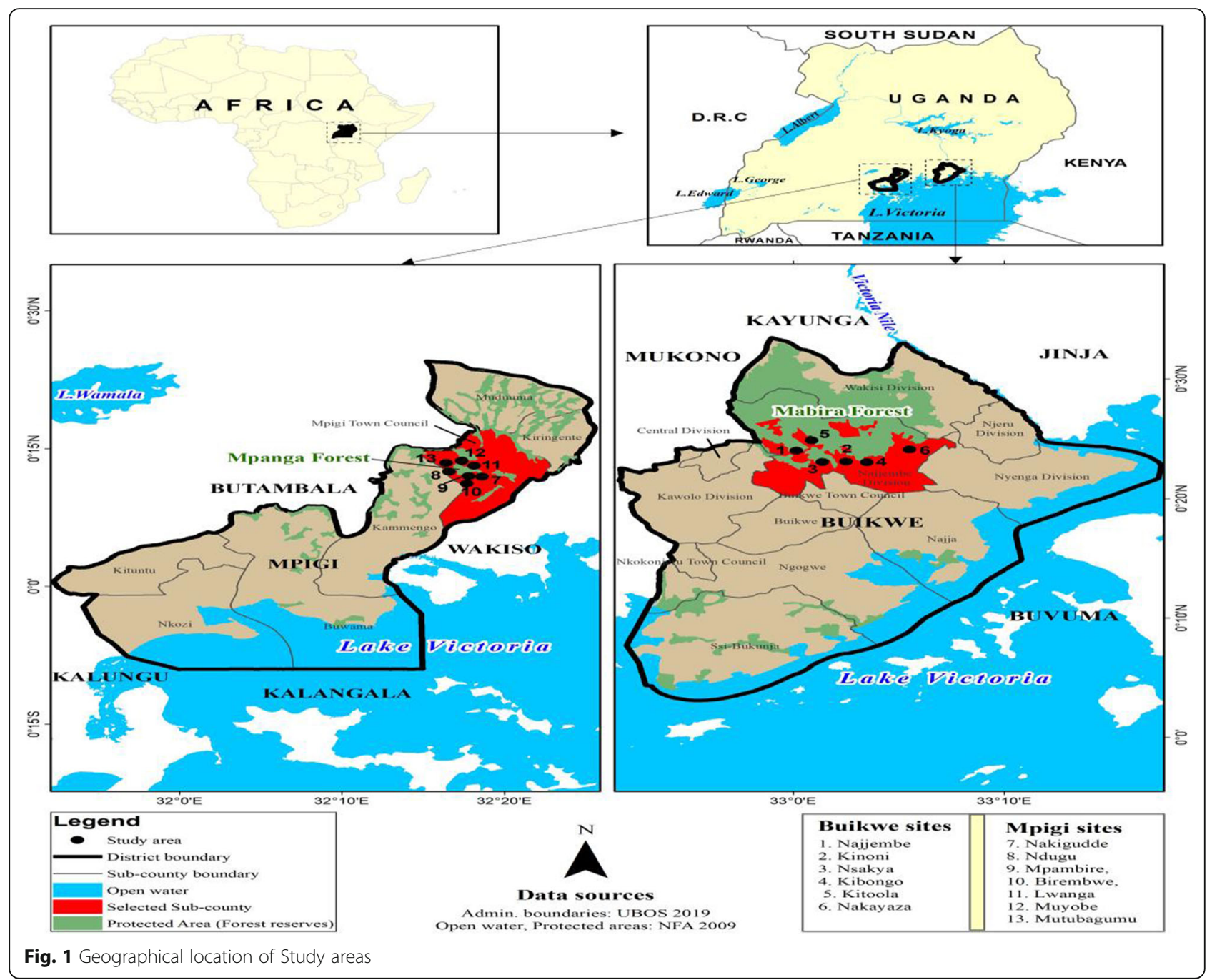

from civil society and environmental activists who were committed to save the Mabira forest because of its rich biodiversity [22].

\section{Data collection and selection of study participants}

Fieldwork for this study was conducted between April and June 2018. The key respondents who were mainly herbalists and community elders were selected using purposive and snowball sampling methods [23]. The respondents were selected from each parish and village on the basis of their reputation and ability to demonstrate good traditional herbal medicine knowledge. For each respondent, we recorded personal information on gender, age, and marital status. We also recorded information on the respondent's location, the level of education, and how they acquired knowledge about medicinal plants. Before the interviews started, voluntary verbal prior informed consent of each of the informants was obtained. Since the knowledge is a natural wealth of the local people, they were assured that the data would be used only for academic purposes. After explaining the purpose of our study, we recorded information on medicinal plants and their use, plant parts used, diseases treated, the preparation and administration methods, and the conservation status (availability of the plants). Ethnobotanical data were obtained by means of semi-structured interviews and questionnaires based on standard ethnobotanical methods $[24,25]$. Interviewees were also asked for the source of their knowledge in order to eliminate the information of secondary nature. Interviews were conducted in Luganda local language. The international plant name index (www.ipni.org) and the Royal Botanic Garden Kew (www.theplantlist.org) were used to validate plant scientific names, families, and authorities. Voucher specimens were identified by comparing with herbarium specimens at the National herbarium at Makerere University, Kampala, Uganda. 


\section{Quantitative analysis of ethnobotanical data}

Data were entered in an Excel sheet, and frequencies and percentages were used to summarize ethnobotanical data. These parameters were used to check for informant consensus factor (ICF), fidelity level (FL), and percentage respond knowledge (PRK) [26]. In addition, validation and homogeneity of the collected information were done by using ICF and PRK while fidelity level was used to get the percentage of respondents claiming to use a particular plant species for the same major purpose. These indices are also applied to select potential plant species for further pharmacological studies and recommendation in drug development [27].

\section{Informant consensus factor (ICF)}

Informant consensus factor (ICF) for different ailment categories was calculated for testing homogeneity or consistency of the informants' knowledge about a particular remedy for a particular ailment. It is used to highlight plants of cultural relevance and agreement in the use of plants $[28,29]$. The index is calculated as follows: $\mathrm{ICF}=\mathrm{N}_{\mathrm{ur}}-\mathrm{N}_{\mathrm{t}} / \mathrm{N}_{\mathrm{ur}}-1$ where $\mathrm{N}_{\mathrm{ur}}$ is the number of useful reports in each category and $\mathrm{N}_{t}$ is the number of species (taxa) in each category. The value of this factor ranges from 0 to 1 . A high ICF value indicates an agreement among respondents in the use of taxa within a medicinal category. The relative importance of a species is evaluated by the proportion of respondents who cited it.

\section{Percentage of respondent knowledge (percent use-value)}

The percentage of respondents who have knowledge (PRK) regarding the use of a species in the treatment of diseases was estimated using the formula:

Number of people interviewed citing the species Total number of respondents interviewed $\times 100$

The percent use-value index determines the relative importance of plant species as a medicinal plant [30-34]. High PRK indicates high use reports for a plant implying its relative importance to the local community for health care needs.
Fidelity level (FL)

Fidelity level (FL) is the percentage of respondents who mention the use(s) of a certain plant species to treat a particular ailment. It indicates the respondents' choice for a potential plant species to treat a given ailment $[27,34,35]$ and is calculated using the formula: $\mathrm{FL}$ $(\%)=\mathrm{Np} / \mathrm{N} \times 100$ where $\mathrm{Np}$ is the number of informants that claimed use of a particular plant species for a particular disease and $\mathrm{N}$ is the total number of informants citing the species for any disease. The maximum FL indicates the frequency and high use of the species for treating a particular ailment by the informants in the study area. FL is designed to quantify the importance of a species for a given purpose.

\section{Rahman's similarity index (RSI)}

This similarity index was used to find out the similarities and differences in traditional medicine knowledge in different study areas [36]. The similarity index shows cultural similarities between ethnic groups in the study areas by calculating particular plant species and same medicinal usage. The percentage of common uses between two study areas can be obtained using the formula [37].

$$
\mathrm{RSI}=\frac{\mathrm{d}}{\mathrm{a}+\mathrm{b}+\mathrm{c}-\mathrm{d}} \times 100
$$

where $\mathrm{a}$ is the number of species unique in an area $\mathrm{A}$ (Mpanga), $b$ is the number of species unique in an area $\mathrm{B}, \mathrm{C}$ is the number of common species in both $\mathrm{A}$ and $\mathrm{B}$, and $d$ is the number of common species used for similar ailments in both areas.

\section{Results}

\section{Respondent characteristics}

Among the 28 respondents interviewed in this study, 19 (68\%) were women and the rest were men. Respondents had low education levels whereby 22 respondents (79\%) out of 28 had not attended any formal education. Respondents obtained plant knowledge from their parents, grandparents, and fellow herbalists. The majority (71\%) of respondents were above 40 years of age (Table 1). Ninety-six percent (96\%) of respondents were married.

Table 1 Demographic profile of respondents $(n=28)$

\begin{tabular}{llllllll}
\hline Variable & Categories & Count & Percentage & Variable & Categories & Count & Percentage \\
\hline Gender & Female & 19 & 68 & Marital status & Married & 27 & 96 \\
& Male & 9 & 32 & & Widow & 1 & 04 \\
Age & $20-29$ & 3 & 11 & Education & Secondary & 4 & 07 \\
& $30-39$ & 5 & 18 & & Primary & 2 & 14 \\
& $>40$ & 20 & 71 & None & 22 & 79 \\
\hline
\end{tabular}


Table 2 Ten most frequently reported diseases and species with high PRK

\begin{tabular}{llll}
\hline S/N & Plant species & Number of diseases & PRK \\
\hline 1 & Hoslundia opposita Vahl. & 22 & 71 \\
2 & Mangifera indica L. & 4 & 57 \\
3 & Momordica foetida Schumach. & 13 & 57 \\
4 & Bryophyllum pinnatum (Lam.) Oken & 18 & 54 \\
5 & Piptadeniastrum africanum (Hook.f) Brenan & 15 & 50 \\
6 & Dracaena steudneri Engl. & 12 & 46 \\
7 & Erythrina abyssinica DC. & 10 \\
8 & Bidens pilosa L. & 7 \\
9 & Tetradenia riparia (Hochst.) Codd & 7 \\
\hline
\end{tabular}

\section{Medicinal plant uses and conservation of the plant species} A total of 136 medicinal plant species belonging to 55 families and 119 genera were reported to treat 57 disease conditions in both study areas. Mpanga and Mabira communities recorded 173 and 90 medicinal plant species, respectively, where 48 were common to both areas, and 24 plants had similar uses. The most abundant taxa were reported for Fabaceae (11\%) and Asteraceae (9\%) families. Plant species were found to be used in the management of more than one ailment, for instance, Hoslundia opposita Vahl (22 conditions) and Piptadeniastrum africanum (Hook.f) Vahl (15 conditions) (Table 2). Some similar species were found in both forests and used to treat the same ailments, for instance, Psorospermum febrifugum Spach, Dracaena steudneri Engl, and Centella asiatica (L.) Urb was commonly used by communities from both areas (Appendix 1). However, some plants were unique to each of the forest reserves, for instance, Croton macrostachyus Hochst. Ex Delile and Abrus canescens Baker were only found in the Mabira forest reserve. It was also noted that females recorded the highest number of plants in both areas (123 for Mpanga and 56 for Mabira) while males recorded 50 plant species from Mpanga and 34 from Mabira. Similarly, in the Mpanga forest, we recorded 56 and 24 diseases to be treated by women and men, respectively. In Mabira, there were 31 and 57 diseases treated by females and males, respectively.

Throughout the study areas, $61 \%$ of medicinal plants grew in their natural (wild) environments (Fig. 2).

Wild habitats included forests, bushes, open land, and fallow land. Forty-four plant species (36\%) were not easy to get from the natural environment, hence considered rare and threatened, while 10 plants $(8 \%)$ occurred both in natural and cultivated habitats.

Different plant parts and biological forms were used in herbal medicine preparations (Table 2). Leaves contributed $50 \%$ of plant parts used to prepare herbal remedies (Fig. 3). However, for most plants, more than one plant part was used.

Herbs contributed $54 \%$ of biological forms used in herbal remedy preparation (Fig. 4)

\section{Herbal remedy preparation and administration}

The most common methods of preparation and administration of medicinal drugs were decoction (31\%) and oral intake (36\%) respectively (Fig. 5 and Fig. 6).

\section{Percentage respondents' knowledge (percentage use-value)}

Figure 7 shows plants that were mentioned by more than $40 \%$ of respondents. The highest cultural importance was

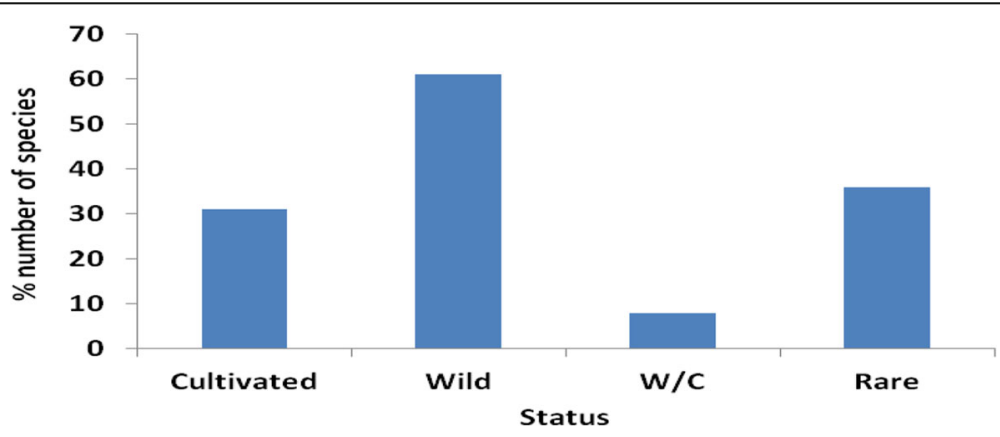

Fig. 2 Conservation of the medicinal plant species 


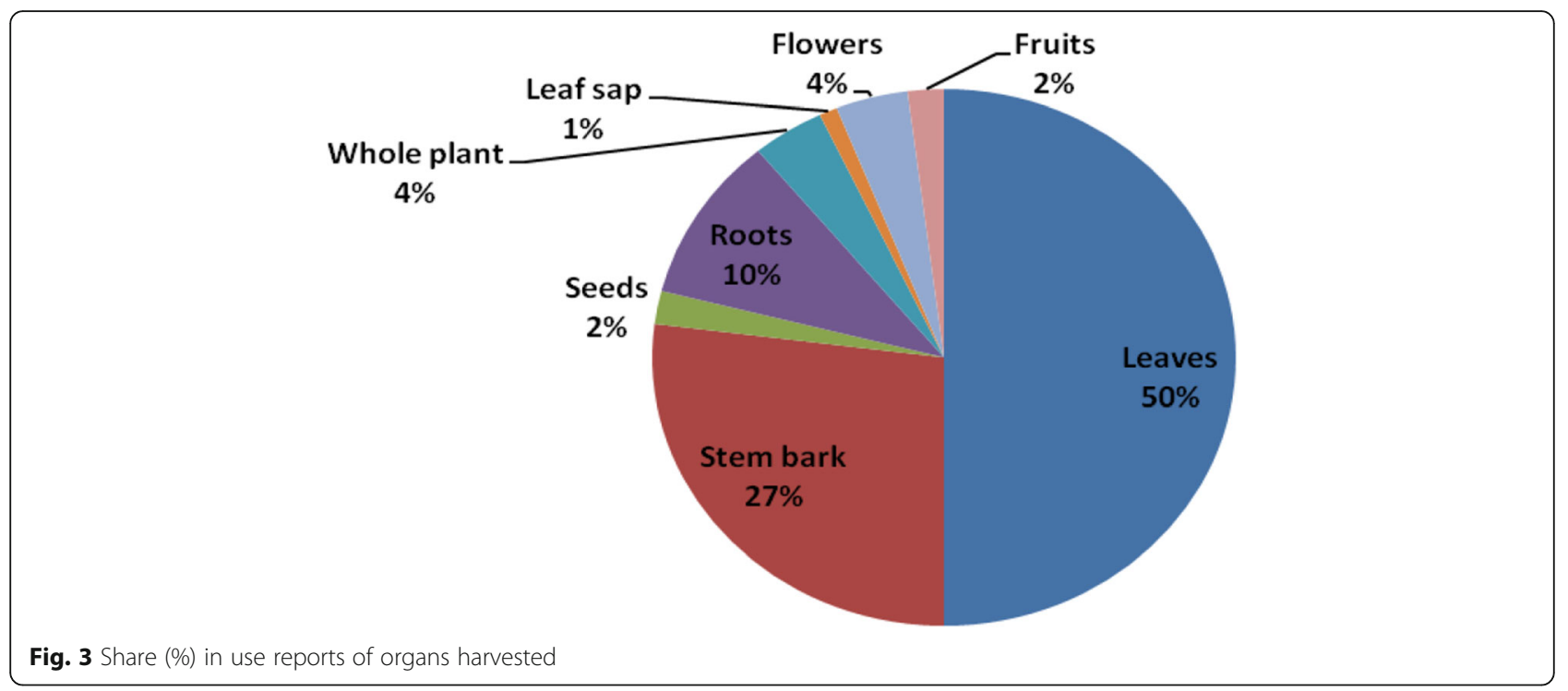

calculated for Hoslundia opposita Vahl. having the highest percentage (71\%) of mention by respondents.

\section{Informants' knowledge and consensus about medicinal plants (ICF)}

A total of 57 disease conditions were recorded and grouped into 14 use categories (Table 3 ). The category of digestive disorders presented the highest number of diseases (16\%) as well as plant species used (44\%). This was followed by respiratory system disorders and dermatological with $38 \%$ and $36 \%$ of plant species, respectively. Informant consensus factor (ICF) was calculated for each disease category and respiratory system disorders had the highest ICF of 0.7 .

\section{Fidelity levels of frequently reported plant species}

The highest fidelity level (FL: 100\%) was from Bidens pilosa L. for wounds and from Callistemon citrinus

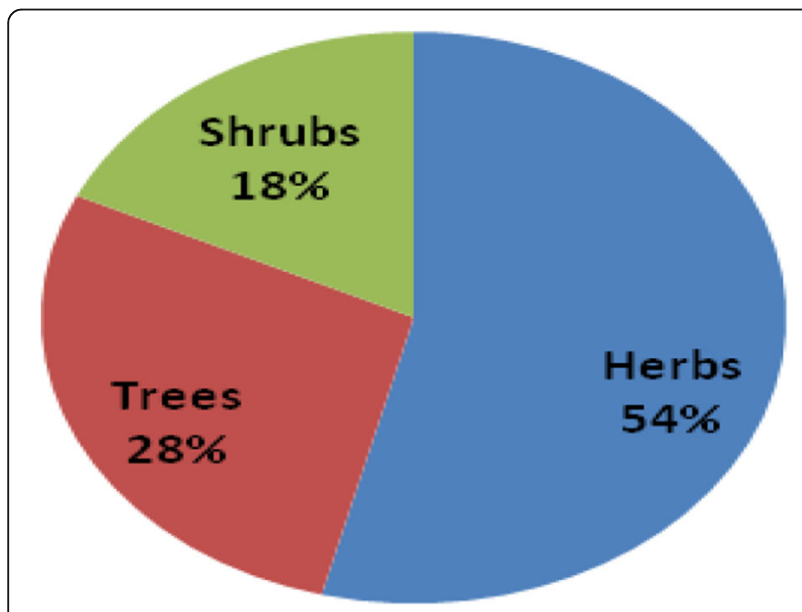

Fig. 4 Share (\%) in medicinal plant use reports of biological forms
(Curtis) Skeels for cough. The fidelity level for the rest of the frequently reported plants ranged from 47 to $80 \%$ (Table 4).

\section{Rahman's similarity index (RSI)}

Using Rahman's similarity index, the study shows $8.4 \%$ similarity between ethnic communities of Mabira and Mpanga where 24 plant species were common in medicinal usage to both study areas.

\section{Discussion}

The use of medicinal plants in and around Mabira and Mpanga forest reserves is similar to many parts of the country. As seen in other communities, traditional healing is practiced by both men and women $[5,29]$. The transfer of knowledge of medicinal plants from one generation to another that was mentioned in this study had been noted also by other researchers [5, 30]. It is also common practice for children and grandchildren to accompany their parents during the harvesting of medicinal plants and at the time of treating patients. This is how indigenous knowledge is acquired through time as it is handed down from one generation to another through transfer from parents to children and friends.

The dominance of some plant species in both forests could be due to the similar geographical and climatic conditions. From the results of Rahman's similarity index $($ RSI $=8.4 \%)$, the study shows that there is low ethnocultural similarity in the use of medicinal plants between the two communities. However, Mpanga recorded the highest number of plant species. The plants recorded in this study have been found to be used else elsewhere in other studies for similar or different ailments. For instance, in a study done in other villages adjacent to Mabira forest reserve [31], Entada abyssinica 


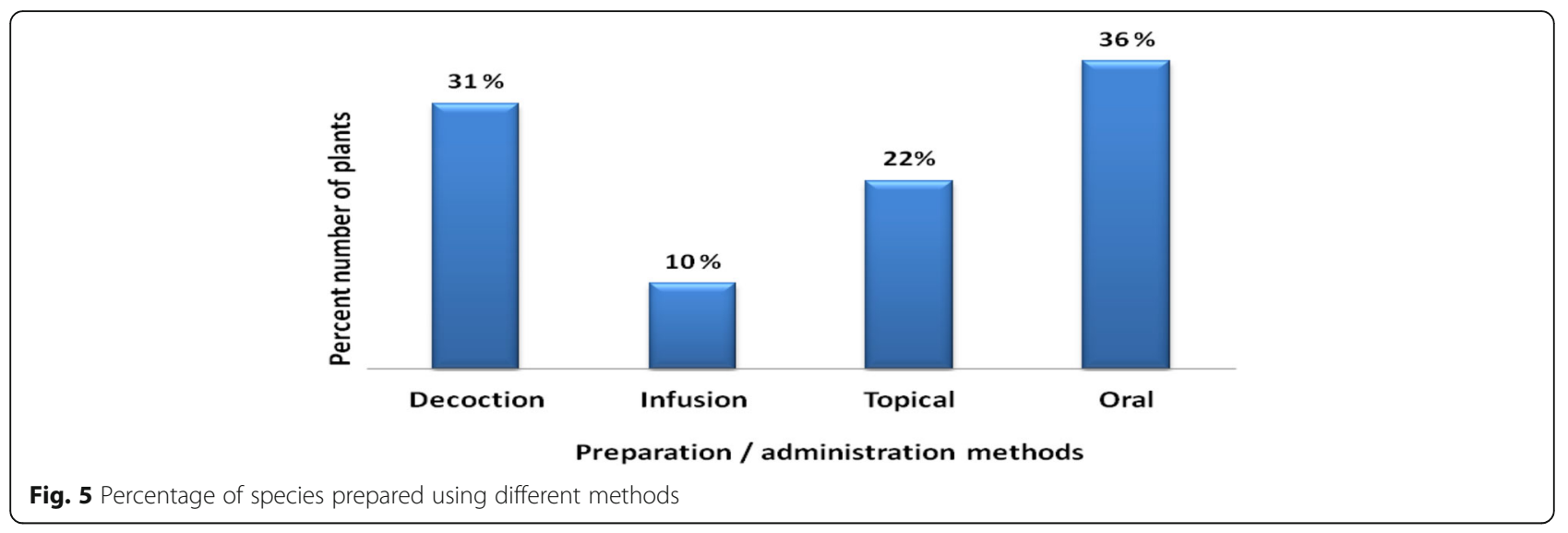

A. Rich was reported for skin infections and wounds; Oxygonum sinuatum (Hochst \& Steud ex Meisn) Dammer for boils; Callistemon citrinus (Curtis) Skeels for cough; and Rhus vulgaris Meikle for skin infections, among others. This shows the cultural importance of these plants to these communities.

In our study, the predominance of Fabaceae, Asteraceae, and Lamiaceae families in medicinal use is not new as studies from other researchers report similar findings $[7,9,11,32,33,35,38,39]$. Fabaceae is the third-largest family and is of great ethnobotanical importance in indigenous and urban communities throughout the world [40]. The family Fabaceae has also been reported in other studies to treat anemia, diarrhea, and cancer [41]. The therapeutic properties of Fabaceae are attributed to the presence of flavonoids (the main constituents), tannins, saponins, alkaloids, and terpenes which are known to possess high levels of bioactivity. The active compounds from this family possess antibacterial, antioxidant, and antifungal activities [41]. This may justify their use in the treatment of skin infections, cough, ear infections, cancer, wounds, and syphilis as reported in this study.

The predominance of harvesting plants from the wild has been observed in other studies where over 100 different types of medicines were collected from natural forests [42]. This puts the key plant species at risk of disappearing since they are threatened by human activities like agriculture and seasonal variations. This study recorded Milicia excelsa (Welw) C.C. Berg as threatened. This species also appears under the Red List of threatened species of Uganda 2018 [43].

The use of different plant parts ranging from leaves, roots, fruits, seeds, and whole plants for herbal remedy preparation has been recorded by other researchers [8-11, 44]. The predominance of using leaves, biological form (herbs), mode of preparation (decoction), and administration (oral intake) methods has been observed in earlier ethnobotanical studies [7, 11, 19, 31, 45-47]. The predominance in the use of leaves could be due to their fast regeneration [11] and the photosynthetic and biosynthetic

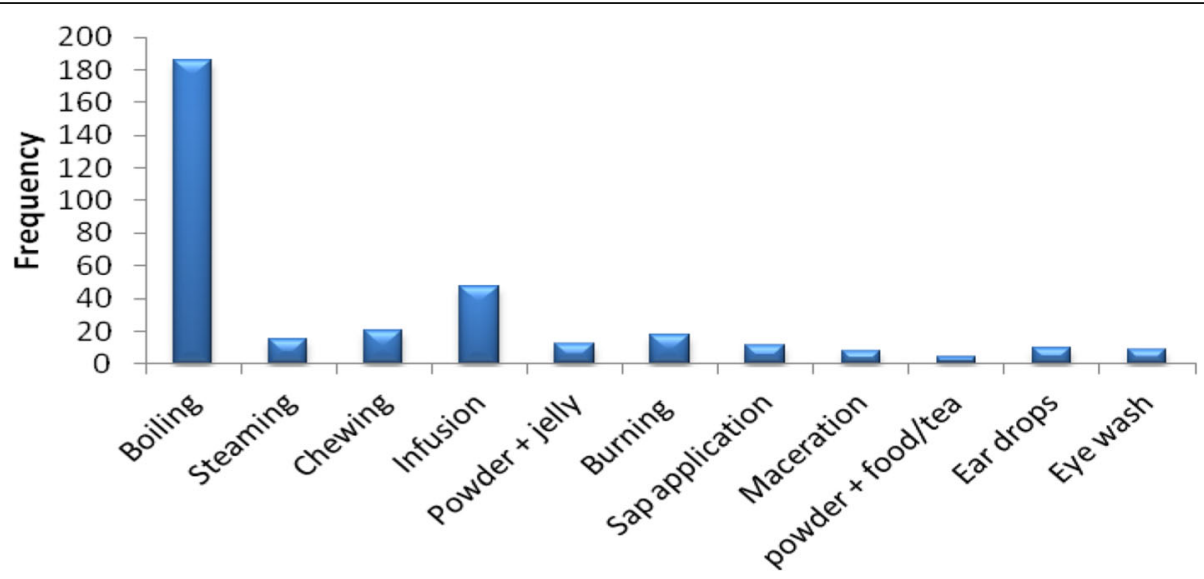

Fig. 6 Methods of preparing herbal remedies 


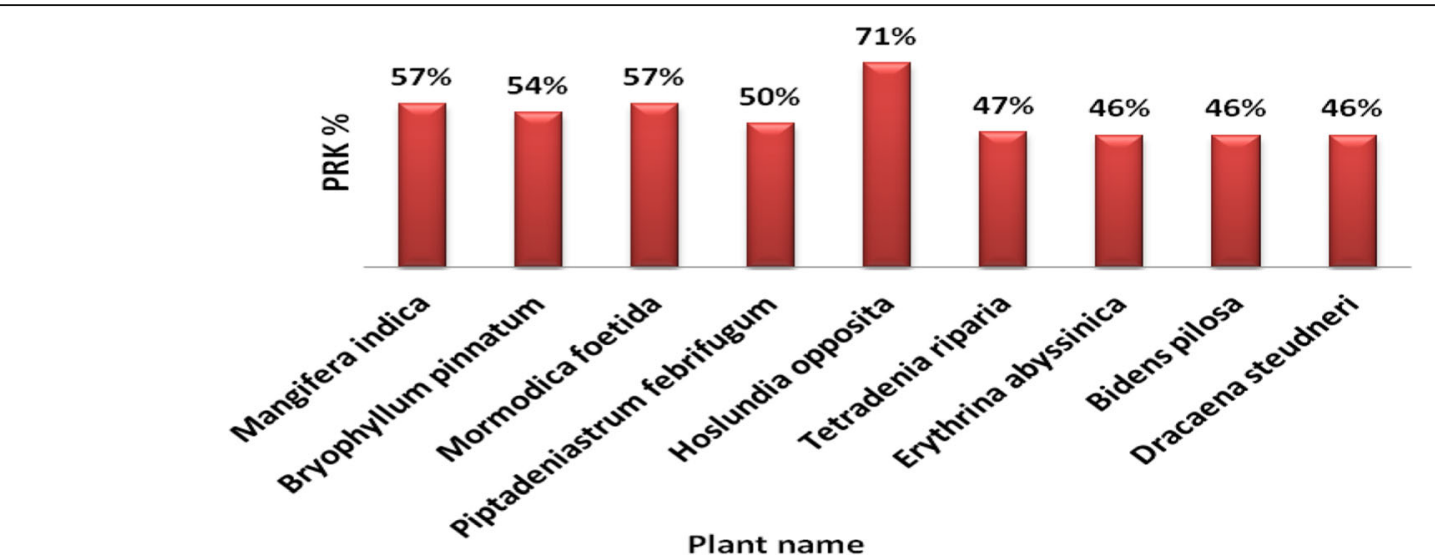

Fig. 7 Ranking of most important medicinal plant species according to PRK

activities which lead to the production of most bioactive substances [8].

The use of plant mixtures for herbal remedy preparation was also reported in other studies [48], and this could be due to the additive or synergistic effects of the combined plant compounds that act on different pathogens.

The highest frequency of mention of Hoslundia opposita Vahl for treating various ailments has also been reported elsewhere [49]. This could be due to the numerous pharmacological compounds and properties that the plant contains [49].
The highest ICF (0.71) which was recorded for respiratory disorders has been reported to be the dominant disease category in other study areas $[46,47,5,4,51,11]$.

Bidens pilosa and Callistemon citrinus had a fidelity level of $100 \%$ and ranked highest in treatment of wounds and cough, respectively. The potential of these plants to treat the same ailments has been reported by other authors $[7,11,14,41,49-54]$.

\section{Conclusion}

The people in and around Mabira and Mpanga forest reserves widely use medicinal plants to manage various

Table 3 Ailment categories treated by different medicinal plants

\begin{tabular}{|c|c|c|c|c|}
\hline Use category & Ailments & $\begin{array}{l}\text { Use } \\
\text { citation }\end{array}$ & $\begin{array}{l}\text { Number of } \\
\text { species used }\end{array}$ & $\overline{I C F}$ \\
\hline Cancers & Cancer and tumors & 16 & 13 & 0.15 \\
\hline Cardiovascular disorders & Anemia, high blood pressure, palpitations, cleansing blood vessels & 35 & 25 & 0.32 \\
\hline Dermatological disorders & Wounds, inflammation, skin rash, boils, warts, athletes' foot, Paronychia & 120 & 50 & 0.60 \\
\hline $\begin{array}{l}\text { Gastrointestinal/digestive } \\
\text { disorders }\end{array}$ & $\begin{array}{l}\text { Stomachaches, ulcers, colic pain, vomiting, deworming, diarrhea, appetite } \\
\text { boosting, dysentery, constipation }\end{array}$ & 103 & 60 & 0.42 \\
\hline Ear, nose, and throat & Ear infections, sore throat, nose bleeding & 38 & 26 & 0.32 \\
\hline $\begin{array}{l}\text { Infectious \& parasitic } \\
\text { diseases }\end{array}$ & Malaria, headache, measles, brucella, jaundice, migraine, dizziness, hernia & 48 & 29 & 0.40 \\
\hline Metabolic disorders & Diabetes, dehydration & 6 & 5 & 0.20 \\
\hline $\begin{array}{l}\text { Muscular and joint } \\
\text { disorders }\end{array}$ & Chest pain, back pain, arthritis, broken \& painful bones, neck pain,' & 18 & 16 & 0.12 \\
\hline Nervous system disorders & Meningitis, convulsions, memory boost, mental illness and paralysis & 16 & 15 & 0.1 \\
\hline Opthalmia & Itching eyes, cataract, eye infections & 29 & 16 & 0.50 \\
\hline Reproductive health care & $\begin{array}{l}\text { Blocked fallopian tubes, sexual dysfunction, antenatal care, miscarriages, } \\
\text { barrenness, sexual dysfunction, fibroids }\end{array}$ & 35 & 26 & 0.26 \\
\hline $\begin{array}{l}\text { Respiratory system } \\
\text { disorders }\end{array}$ & Cough, asthma, tuberculosis, sinuses & 171 & 53 & 0.70 \\
\hline $\begin{array}{l}\text { Sexually transmitted } \\
\text { infections (STISs) }\end{array}$ & Syphilis, gonorrhea & 76 & 40 & 0.50 \\
\hline Other purposes & Blessings, good luck, witchcraft, septic arthritis, Splenomegally & 20 & 16 & 0.2 \\
\hline
\end{tabular}


Table 4 Fidelity levels of the frequently reported plants and their major uses

\begin{tabular}{|c|c|c|c|c|c|}
\hline Plant species & Family & Therapeutic use & $\mathrm{N}_{\mathrm{p}}$ & $\mathbf{N}$ & FL (\%) \\
\hline Bidens Pilosa L. & Asteraceae & Wounds & 7 & 7 & 100 \\
\hline Erythrina abyssinica DC & Fabaceae & Cough & 10 & 16 & 63 \\
\hline Mangifera indica $\mathrm{L}$. & Anacardiaceae & Cough & 16 & 20 & 80 \\
\hline Psidium guajava $\mathrm{L}$. & Myrtaceae & Cough & 6 & 10 & 60 \\
\hline Callistemon citrinus (Curtis) Skeels & Myrtaceae & Cough & 4 & 4 & 100 \\
\hline Vernonia cinerea $(\mathrm{L})$ Less & Asteraceae & Sore throat & 4 & 7 & 57 \\
\hline Psorospermum febrifugum Spach & Clusiaceae & Skin infections & 4 & 7 & 57 \\
\hline Entada abyssinica A. Rich & Fabaceae & Skin infections & 4 & 6 & 67 \\
\hline Dracaena steudneri Engl. & Dracaenaceae & Syphilis & 7 & 15 & 47 \\
\hline
\end{tabular}

Key: Column 4: Np- number of respondents who use a species for a specific ailment Column 5: N- total number of informants who mentioned the plant for any other use Column 6: FL fidelity level

human ailments. This shows that the preservation and conservation of indigenous knowledge are vital for the sustainable utilization of the plant resources. There is a need for immediate conservation of the threatened and disappearing species to avoid their extinction from the wild. Plants with high informant agreement and fidelity level values can be subjected to further pharmacological studies to validate their traditional uses. This can also lead to the discovery of new bioactive molecules. The reported ethnobotanical studies by other researchers validate the use of the recorded plants in the treatment of the mentioned ailments, although further investigations need to be done in areas of pharmacology and toxicology.

\section{Supplementary Information}

The online version contains supplementary material available at https://doi. org/10.1186/s41182-021-00341-z.

Additional file 1: Appendix 1. Ethnobotanical data on the medicinal plant species used in the study areas.

\section{Acknowledgements}

The authors are grateful to the Carnegie Corporation for funding this project. Special gratitude to the communities of Mabira (Buikwe District) and Mpanga (Mpigi District) for sharing their knowledge with us and helping in plant collection. We are grateful to the taxonomist, Mr. Protase Rwaburindore, for identifying the plant material.

\section{Authors' contributions}

Namukobe conceptualized the study and designed the methods. Asiimwe, Namukobe, and Imalingat conducted the survey, analyzed the data, and drafted the manuscript. Robert participated in reviewing the manuscript. All authors worked together to produce this manuscript. The authors read and approved the final manuscript.

\section{Funding}

This study was funded by the Carnegie Cooperation of New York through the Makerere University School of Graduate Research and Training.

\section{Availability of data and materials}

All data generated during the survey and analyzed is available on request from the corresponding author.

\section{Declarations}

\section{Ethics approval and consent to participate}

All study participants gave their voluntary oral prior informed consent before the commencement of the study. Voucher specimens of the plant species mentioned in the study were collected using the international standard procedures laid out in the book "Ethnobotany" by Martin (1995).

Consent for publication

All study participants gave their consent for publication.

\section{Competing interests}

The authors declare that they have no competing interests.

\section{Author details}

'Department of Plant Sciences, Microbiology \& Biotechnology, Makerere University, P.O Box 7062, Kampala, Uganda. ${ }^{2}$ Department of Chemistry, Makerere University, P.O Box 7062, Kampala, Uganda.

Received: 18 February 2021 Accepted: 4 June 2021

Published online: 29 June 2021

\section{References}

1. Ahmed HM. Ethnopharmacobotanical study on the medicinal plants used by herbalists in Sulaymaniyah Province, Kurdistan, Iraq. J Ethnobiol Ethnomed. 2016:12(1):1-7.

2. Abayomi S, Eyitope $\mathrm{O}$, Adedeji $\mathrm{O}$. The role and place of medicinal plants in the strategies for disease prevention. Afr J Tradit Comp Altern Med. 2013; 10(5):210-29.

3. Ozioma EO, Chinwe OA. Herbal medicines in African traditional medicine. J. Herb. Med. 2019:10:191-214.

4. Abdullahi AA. Trends and challenges of traditional medicine in Africa. Afr. J. Tradit. Complement. Altern. Med. 2011:8(5S):115.

5. Asiimwe S, Kamatenesi-Mugisha M, Namutebi A, Borg-Karlsson AK, Musiimenta P. Ethnobotanical study of nutri-medicinal plants used for the management of HIV/AIDS opportunistic ailments among the local communities of western Uganda. J. Ethnopharmacol. 2013;150(2):639-48. https://doi.org/10.1016/j.jep.2013.09.017.

6. Asiimwe S, Namutebi A, Borg-Karlson AK, Mugisha MK, Kakudidi EK, Hannington OO. Documentation and consensus of indigenous knowledge on medicinal plants used by the local communities of western Uganda. J. Nat. Prod. Plant Resour. 2014:4(1):34-42.

7. Nambeja C, Tugume P, Nyakoojo C, Kamatenesi-Mugisha M. Medicinal plant species used in the treatment of skin diseases in Katabi sub-county, Wakiso district, Uganda. Ethnobot. Res. Appl. 2019;18:1-7.

8. Adia MM, Anywar G, Byamukama R, Kamatenesi-Mugisha M, Sekagya Y, Kakudidi EK, et al. Medicinal plants used in malaria treatment by Prometra herbalists in Uganda. J. Ethnopharmacol. 2014;155(1):580-8. https://doi.org/1 0.1016/j.jep.2014.05.060. 
9. Anywar G, Kakudidi E, Byamukama R, Mukonzo J, Schubert A, Oryem-Origa H. Data on medicinal plants used by herbalists for boosting immunity in people living with HIV/AIDS in Uganda. Data brief. 2020;29:105097. https:// doi.org/10.1016/j.dib.2019.105097.

10. Kisangau DP, Lyaruu HV, Hosea KM, Joseph CC. Use of traditional medicines in the management of HIV/AIDS opportunistic infections in Tanzania: a case in the Bukoba rural district. J. Ethnobiol. Ethnomed. 2007;3(1):1-8.

11. Namukobe J, Kasenene JM, Kiremire BT, Byamukama R, Kamatenesi-Mugisha M, Krief $\mathrm{S}$, et al. Traditional plants used for medicinal purposes by local communities around the Northern sector of Kibale National Park, Uganda. J. Ethnopharmacol. 2011;136(1):236-45. https://doi.org/10.1016/j.jep.2011.04.044

12. Omotayo FO, Borokini TI. Comparative phytochemical and ethnomedicinal survey of selected medicinal plants in Nigeria. Sci Res Essays. 2012;7(9):989-99.

13. Ssozi L, Kabiito B, Byaruhanga A, Kanata W. Documenting Baganda Ethnomedicine: a Step towards Preservation and Conservation. J. Adv. Res. 2016 1(2):15-22. https://doi.org/10.21839/jaar.2016.v1i2.20.

14. Tugume $P$, Nyakoojo C. Ethno-pharmacological survey of herbal remedies used in the treatment of paediatric diseases in Buhunga parish, Rukungiri District, Uganda. BMC Compl Alternative Med 2019;19(1):1-0.

15. Uganda-Gazzette. Indigenous and Complementary Medicine Bill, VIII: Bill No. 7. 2015

16. Sekaja Y, Aryeija W, Bitwari U. Traditional medicine in Uganda: historical perspective challenges and advances. IK Notes. World Bank. 2004.

17. NFA, 2019. Mpanga Forest Reserve. https://nfa.org.ug/index.php/11-ecotourism/92-mpanga-central-forest-reserve: accessed February 2021.

18. Jovanelly TJ, Okot-Okumu J, Godwin E. A preliminary investigation to water and soil quality in four forest reserves near Kampala, Uganda. J. Environ. Hydrol. 2012;6(20):1-9.

19. Mpigi District Local Government M. In: Government, M.D.L. (Ed.). Health Department. 2020. https://www.mpigi.go.ug/department/health, Kampal: Accessed Apr 2021.

20. Molares S, Ladio A. The usefulness of edible and medicinal Fabaceae in Argentine and Chilean Patagonia: environmental availability and other sources of supply. Evid-based Compl Alt. 2012;2012:1-12. https://doi.org/1 $0.1155 / 2012 / 901918$

21. Langdale-Brown I, Osmaston HA, Wilson JG. The vegetation of Uganda and its bearing on land-use; 1964

22. Nakkazi, E. Ugandans to mobilize to save Mabira forest from sugarcane plantation, Ecologist. 2011. The Journal for the Post-industrial age. https:// theecologist.org/2011/sep/20/ugandans-mobilise-save-mabira-forest-sugarca ne-plantation. Accessed February 2021.

23. Ghaljaie F, Naderifar M, Goli H. Snowball sampling: a purposeful method of sampling in qualitative research. Stride Dev Med Educ. 2017;14(3). Accessed May 2021.

24. Cunningham AB. Applied ethnobotany: people, wild plant use and conservation. Earthscan. 2001;320

25. Maroyi A, et al. J. Ethnopharmacol. 2011;136(2):347-54. https://doi.org/10.1 016/j.jep.2011.05.003.

26. Ugulu I. Fidelity level and knowledge of medicinal plants used to make therapeutic Turkish baths. Stud Ethno-Med. 2012;6(1):1-9. https://doi.org/1 0.1080/09735070.2012.11886413.

27. Umair M, Altaf M, Abbasi AM. An ethnobotanical survey of indigenous medicinal plants in Hafizabad district, Punjab-Pakistan. PloS one. 2017;12(6): e0177912. https://doi.org/10.1371/journal.pone.0177912.

28. Trotter RT, Logan MH. Informant consensus: a new approach for identifying potentially effective medicinal plants. In: Etkin NL, editor. Plants in Indigenous Medicine and Diet, Behavioural Approaches. Bredfort Hills, New York: Redgrave Publishing Company; 1986. p. 91-112.

29. Abe R, Ohtani K. An ethnobotanical study of medicinal plants and traditional therapies on Batan Island, the Philippines. J.Ethnopharmacol. 2013;145(2):554-65. https://doi.org/10.1016/j.jep.2012.11.029.

30. Phillips O, Gentry AH, Reynel C, Wilkin P, Gálvez-Durand BC. Quantitative ethnobotany and Amazonian conservation. Conserv. Biol. 1994;1:225-48.

31. Tugume P, Kakudidi EK, Buyinza M, Namaalwa J, Kamatenesi M, Mucunguzi $P$, et al. Ethnobotanical survey of medicinal plant species used by communities around Mabira Central Forest Reserve, Uganda. J. Ethnobiol. Ethnomedicine. 2016;1:1-28.

32. Friedman J, Yaniv Z, Dafni A, Palewitch D. A preliminary classification of the healing potential of medicinal plants, based on a rational analysis of an ethnopharmacological field survey among Bedouins in the Negev Desert,
Israel. J. Ethnopharmacol. 1986;16(2-3):275-87. https://doi.org/10.1016/03788741(86)90094-2.

33. Alexiades MN. Collecting ethnobotanical data: an introduction to basic concepts and techniques. Adv. Econ Bot. 1996;10:53-94.

34. Tsioutsiou EE, Giordani P, Hanlidou E, Biagi M, De Feo V, Cornara L. Ethnobotanical study of medicinal plants used in central Macedonia, Greece. Evid-based Compl Alt. 2019;2019:4513792.

35. Heinrich M. Ethnobotany and its role in drug development. Phytother Res. 2000;7:479-88.

36. ljaz F, Iqbal Z, Rahman IU, Alam J, Khan SM, Shah GM, et al. Investigation of traditional medicinal floral knowledge of Sarban Hills, Abbottabad, KP Pakistan. Journal of Ethnopharmacology. 2016 Feb 17;179:208-33. https:// doi.org/10.1016/j.jep.2015.12.050.

37. Rahman IU, Hart R, Afzal A, lqbal Z, ljaz F, Abd Allah EF, et al. Appl. Ecol. Environ. Res. 2019:17(2):2765-77.

38. Tefera T, Yihune M. Ethnobotanical study on medicinal plants used by indigenous people in Tenta District, South Wollo, Ethiopia. J. Med. Plant Res. 2019;13(2):47-54.

39. Vendruscolo GS, Mentz A. Ethnobotanical survey of the medicinal plants used by the community of Ponta Grossa neighborhood, Porto Alegre, Rio Grande do Sul, Brazil. Iherigia Série Botânica. 2006;61:83-103.

40. Appiah KS, Oppong CP, Mardani HK, Omari RA, Kpabitey S, Amoatey CA, et al. Medicinal plants used in the Ejisu-Juaben Municipality, southern Ghana: an ethnobotanical study. Medicines. 2019;6(1):1.

41. Kigen G, Kipkore W, Wanjohi B, Haruki B, Kemboi J. Medicinal plants used by traditional healers in Sangurur, Elgeyo Marakwet County, Kenya. Pharmacogn. Res. 2017;4:333.

42. Lamorde M, Tabuti JR, Obua C, Kukunda-Byobona C, Lanyero H, ByakikaKibwika $\mathrm{P}$, et al. Medicinal plants used by traditional medicine practitioners for the treatment of HIV/AIDS and related conditions in Uganda. J. Ethnopharmacol. 2010;130(1):43-53. https://doi.org/10.1016/j.jep.2010.04.004

43. Ssegawa P, Kasenene JM. Medicinal plant diversity and uses in the Sango bay area, Southern Uganda. J. Ethnopharmacol. 2007;113(3):521-40. https:// doi.org/10.1016/j.jep.2007.07.014

44. Ghorbani A. Studies on pharmaceutical Ethnobotany in the region of Turkmen Sahra, north of Iran:(Part 1): general results. J. Ethnopharmacol. 2005:102(1):58-68. https://doi.org/10.1016/j.jep.2005.05.035.

45. Martin GJ. Ethnobotany: a methods manual. Nowy Jork: Chapman y Hall; 1995. https://doi.org/10.1007/978-1-4615-2496-0.

46. Child K. Civil society in Uganda: the struggle to save the Mabira Forest Reserve. J. East. Afr. Stud. 2009;3(2):240-58. https://doi.org/10.1080/17531050902972659.

47. Kayanja Fl, Byarugaba D. Disappearing forests of Uganda: the way forward. Curr Sci. 2001;25:936-47.

48. Senouci F, Ababou A, Chouieb M. Ethnobotanical survey of the medicinal plants used in the Southern Mediterranean. Case study: the region of Bissa (Northeastern Dahra Mountains, Algeria). Pharmacogn. J. 2019:11(4).

49. Said SA. Antimalarial effect and other properties of Hoslundia opposita-a review. Global J Pharm Pharm Sci. 2017:4:1-5.

50. Parada M, Carrió E, Bonet MÀ, Vallès J. Ethnobotany of the Alt Emporda region (Catalonia, Iberian Peninsula): plants used in human traditional medicine. J. Ethnopharmacol. 2009;124(3):609-18. https://doi.org/10.1016/j.jep.2009.04.050.

51. Okot DF, Anywar G, Namukobe J, Byamukama R. Medicinal plants species used by herbalists in the treatment of snakebite envenomation in Uganda. Trop. Med Health. 2020:48:1-4.

52. Kirimuhuzya C. Multi-drug/extensively drug resistant tuberculosis (Mdr/XdrTb): renewed global battle against tuberculosis? Understanding Tuberculosis-New Approaches to Fighting Against Drug Resistance; 2012.

53. Namunana S, Lutoti S, Nyamaizi G, Agaba G, Apun I, Ssebunnya C, et al. Formulation, development and validation of a wound healing herbal ointment from extracts of Bidens pilosa and Aloe barbadensis. J. Pharm Pharmacol Res. 2018;2(2):32-8.

54. Hassan KA, Deogratius O, Nyafuono JF, Francis O, Engeu OP. Wound healing potential of the ethanolic extracts of Bidens pilosa and Ocimum suave. Afr. J. Pharm. Pharmacol. 2011;5(2):132-6. https://doi.org/10.5897/AJPP10.266.

\section{Publisher's Note}

Springer Nature remains neutral with regard to jurisdictional claims in published maps and institutional affiliations. 